\title{
Implementasi Metode Profile Matching dan Multi Factor Evaluation Process (MFEP) Dalam Seleksi Pencari Kerja
}

\author{
Heru Purwanto ${ }^{1}$, Arfhan Prasetyo ${ }^{2}$, Rachmat Suryadithya ${ }^{3}$ \\ ${ }^{1}$ Program Studi Sistem Informasi, Fakultas Teknik \& Informatika, Universitas Bina Sarana Informatika \\ Jl. Kramat Raya no.98 Jakarta Pusat, DKI Jakarta, 10450, Indonesia
}

${ }^{2}$ Program Studi Sistem Informasi Akutansi, Fakultas Teknik \& Informatika, Universitas Bina Sarana Informatika Jl.Merdeka No.168.Kota Bogor, Jawa Barat, Indonesia

${ }^{3}$ Program Studi Sistem Informasi, Fakultas Teknik \& Informatika, Universitas Bina Sarana Informatika Jl. Merdeka No.168 Kota Bogor, Jawa Barat, Indonesia

e-mail : ${ }^{1}$ jovarkan@gmail.com, ${ }^{2}$ arfhan.prasetyo@gmail.com, ${ }^{3}$ rachmat.rcs@bsi.ac.id

Artikel Info : Diterima : 03-07-2021 | Direvisi : 19-07-2021 | Disetujui : 23-07-2021

\begin{abstract}
Abstrak - Proses seleksi pencari kerja yang efektif pada perusahaan sangat dibutuhkan untuk membantu pengambilan keputusan suatu organisasi. Tujuan dari makalah ini adalah untuk membuat sistem dan pengembangan sistem pengambilan keputusan pada bagian sumber daya manusia (SDM) untuk menemukan kemudahan dalam menentukan penilaian kandidat diterima atau tidak.multi factor evaluation process (MFEP) merupakan pendekatan yang sangat efektif dalam menangani masalah keputusan dan profile matching merupakan metode pemilihan multi kriteria, dimana penentuan aspek dan kriteria (nama sekolah, jurusan sesuai, nilai IPK memenuhi, tahun kelulusan, kursus yang relevan, pengalaman kerja dibidang yang sesuai, proyek yang pernah ditangani, kesesuaian gaji yang ditawarkan, domisili, jujur, bertanggungjawab dan disiplin, kerjasama, komunikatif dan percaya diri). Kelebihan dari metode profile matching adanya pemberian Nilai standar dari kriteria utama dan pendukung sehingga memudahkan pengguna sistem dalam menentukan pilihan yang ada MPEF perlu mendefinisikan faktor nilai pendidikan,nilai target dan nilai sikap.Hasil akhir perhitungan memberikan informasi merujuk kepada nama yang sama.Metode profile matching urutan pertama dengan nilai 4,62, urutan kedua 4,59 dan urutan ketiga 4,52. Metode MFEP urutan pertama $=0,513$, urutan kedua $=0,510$ dan urutan ketiga $=0,502$. Sistem ini mendukung keputusan tidak hanya memudahkan penentuan penilaian pencari kerja tetapi juga memberikan alternatif urutan kandidat yang memiliki potensi utk dapat dipertimbangkan oleh perusahaan atau organisasi.
\end{abstract}

Kata Kunci : Pengambilan keputusan, profile matching,MFEP, SDM

Abstracts - An effective job seekers selection process at the company is needed to assist an organization's decision making. The purpose of this paper is to create a system and development of a decision-making system in the human resources (HR) section to find it easier to determine whether job seekers are accepted or not. The multi factor evaluation process (MFEP) is a very effective approach in dealing with decision problems and Profile matching is a multi-criteria selection method, where the determination of aspects and criteria (name of school, appropriate department, GPA value meets, year of graduation, relevant courses, work experience in the appropriate field, projects that have been handled, salary suitability, domicile, honest, responsible and discipline, cooperation, communicative and self-confidence). The advantage of the profile matching method is the provision of standard values from the main and supporting criteria, making it easier for system users to determine the available options. MPEF needs to define the education value factor, target value and attitude value. The final calculation results provide information referring to the same name. Profile Matching method in the first order with a value of 4.62, the second order of 4.59 and the third order of 4.52. The first order MFEP method $=0.513$, the second order $=0.510$ and the third order $=0.502$. This decision support system not only makes it easier to determine the assessment of job seekers but also provides an alternative sequence of candidates who have the potential to be considered by companies or organizations

Keywords: Decision making, profile matching, MFEP, HR

171

This work is licensed under a Creative Commons Attribution-ShareAlike 4.0 International License. 


\section{PENDAHULUAN}

Dalam penentuan karyawan terbaik perusahaan haruslah memiliki SDM yang berkualitas (Sutinah, 2017). Penilaian kinerja karyawan merupakan salah satu untuk yang dilakukan oleh perusahaan dalam pemilihan kandidat karyawan menjadi acuan yang objektif untuk menentukan karyawan yang tepat untuk dapat mengisi posisi yang tepat pula diperusahaan. Pekerjaan dalam menilai karyawan yang akan menjadi pimpinan bukan suatu jaminan dan masih bersifat subjektif (Frieyadie, 2016). Hal ini senada dengan persepsi cara pandang pimpinan terhadap seorang karyawan harus objective (Faizal, 2017). Kendala lain dalam calon karyawan membutuhkan waktu cukup lama bila ada banyak yang melamar pada posisi yang sama (Nashrullah et al., 2016), sehingga sulit untuk menentukan mana kandidat yang cocok, yang akan dipilih. Dukungan kebijakan SDM (human resource policies) serta alat dari sistem penilaian kerja (performance appraisal system and tools) yang secara konsisten diterapkan, artinya tidak terdapat perlakuan khusus bagi orang-orang tertentu.Bila peminat dalam sebuah lowongan pekerjaan sangat tinggi maka akan menjadi kendala dalam selesksi kandidat karyawan (Britta, 2021).

Pengetahuan yang memiliki pola dari kriteria dan alternatif untuk menyelesaikan masalah menjadi pertimbangkan untuk dipilih (Putra et al., 2019). Dalam hal ini metode yang bisa diterapkan adalah metode multi factor evaluation process (MFEP) dapat menghasilkan sistem penunjang keputusan (SPK) yang kolektif dan akurat (Turaina, 2017)(Ramadhan \& Yusfrizal, 2019). Salah satu metode yang bisa diterapkan dalam sistem pendukung keputusan (Ikhlas, 2019) adalah metode multi factor evaluation process (MFEP) (Syahrizal \& Maulidza, 2018) (Afrianty \& Umbara, 2016).Melalui perbandingan metode multyfFactor evaluation process (MFEP) dan profile matching peneliti akan melakukan analisis perbandingnan untuk mendapatkan hasil yang lebih konsisten.(Maharani \& Nata, 2020)

Tujuan penelitan ini membatu menganalisa kandidiat karyawan yang akan diterima di perusahaan dengan kriteria yang telah ditetapkan. Dalam melakukan penilaian calon karyawan dengan memanfaatkan metode profile matching dan multi factor evaluation process berdasarkan pada data dan perhitungan yang lebih baik sebagai pertimbangan penentuan calon karyawan yang akan diterima.

\section{METODE PENELITIAN}

Metode penelitian yang dilakukan dalam untuk pengumpulan data yang dibutuhkan adalah sebagai berikut:

A. Observasi

Mengadakan pengamatan secara langsung mengenai penilaian kebutuhan karyawan pada pusat film nasional (PFN)

B. Wawancara

Dalam pengumpulan data dengan cara tanya jawab secara langsung kepada Bapak Rachamat Suryadithya selaku ketua Tim carrier center yang merekomendasikan calon karyawan .

C. Studi Pustaka

Suatu metode didalam pengumpulan data dengan mengambil literature, selain menggunakan referensi buku-buku yang menunjang.

Profile matching mengasumsikan tiga variables ideal yang harus dimiliki seseorang karyawan. Dalam hal ini tingkat maksimal yang harus dipenuhi. Tingkat gambaran profile persyaratan untuk setiap karyawan ditentukan dengan menggunakan skala dari 1 sampai 6. Makin tinggi tingkatannya, makin penting prioritas profile tersebut maka semakin direkomendasikan.

Cara perhitungan profile matching memiliki tahapan. Adapun Langkah-langkah pada metode profile matching yaitu:

1. Menentukan Variabel Langkah pertama dalam metode profile matching adalah menentukan variabel-variabel yang nantinya digunakan sebagai point penilaian penerimaan karyawan

2. Menghitung pemetaan gap adalah beda antara data nilai dari semua aspek dikurangi nilai standar yang ditetapkan

rumus:

Gap = nilai aspek - nilai standar

Setelah didapatkan tiap gap masing-masing calon karyawan, maka tiap profile karyawan diberi bobot nilai sesuai dengan acuan nilai pada tabel bobot nilai gap. Adapun skala penilaian analisis gap kompetensi atau sering disebut dengan istilah profile matching adalah selisih 0 dengan bobot nilai 6 berarti tidak ada gap atau kompetensi sesuai yang dibutuhkan, selisih 1 dengan bobot nilai 5.5 berarti kompetensi individu kelebihan 1 tingkat/level, selisih 2 
dengan bobot 4.5 berarti kompetensi individu kelebihan 2 tingkat/level, selisih 3 dengan bobot nilai 3.5 berarti kompetensi individu kelebihan 3 tingkat/level, selisih 4 dengan bobot nilai 2.5 berarti kompetensi individu kelebihan 4 tingkat/level, selisih 5 dengan bobot nilai 1.5 berarti kompetensi individu kelebihan 5 tingkat/level, selisih -1 dengan bobot nilai 5 berarti kompetensi individu kurang 1 tingkat/level, selisih -2 dengan bobot nilai 4 berarti kompetensi individu kurang 2 tingkat/level, selisih -3 dengan bobot nilai 3 berarti Kompetensi individu kurang 3 tingkat/level, selisih -4 dengan bobot nilai 2 berarti Kompetensi individu kurang 4 tingkat/level, dan selisih -5 dengan bobot nilai 1 berarti kompetensi individu kurang 5 tingkat/level.

Tabel 1. Bobot Nilai Gap

\begin{tabular}{cccl}
\hline No & Selisih (Gap) & Bobot Nilai & \multicolumn{1}{c}{ Keterangan } \\
\hline 1 & 0 & 6 & Tidak ada Gap (kompetensi sesuai yang dibutuhkan) \\
2 & 1 & 5.5 & Kompetensi individu kelebihan 1 tingkat/level \\
3 & -1 & 5 & Kompetensi individu kurang 1 tingkat/level \\
4 & 2 & 4.5 & Kompetensi individu kelebihan 2 tingkat/level \\
5 & -2 & 4 & Kompetensi individu kurang 2 tingkat/level \\
6 & 3 & 3.5 & Kompetensi individu kelebihan 3 tingkat/level \\
7 & -3 & 3 & Kompetensi individu kurang 3 tingkat/level \\
8 & 4 & 2.5 & Kompetensi individu kelebihan 4 tingkat/level \\
9 & -4 & 2 & Kompetensi individu kurang 4 tingkat/level \\
10 & 5 & 1.5 & Kompetensi individu kelebihan 5 tingkat/level \\
11 & -5 & 1 & Kompetensi individu kurang 5 tingkat/level \\
\hline
\end{tabular}

Sumber:(Sudrajat, 2018)

$N S F=\frac{\Sigma \mathrm{NS}}{\Sigma \mathrm{IS}}$

Keterangan :

NSF : nilai rata-rata secondary factor

NS : jumlah total nilai secondary factor (aspek 1, aspek 2, aspek 3, dst.)

IS : jumlah item secondary factor

3. Menghitung nilai total tiap aspek dari hasil perhitungan dari tiap aspek tersebut kemudian dihitung nilai total berdasarkan dari core factor dan secondary factor yang diperkirakan berpengaruh terhadap kinerja tiap-tiap profile.

Perhitungannya dapat menggunakan pada rumus

Nilai total $=60 \%+40 \% N S F$

Keterangan :

$\mathrm{NCF}$ : nilai rata-rata core factor

NSF : nilai rata-rata secondary factor

Suatu metode dengan menggunakan beberapa faktor dan kriteria yang menggunakan dan melakukan perhitungan kriteria pembobotan dimana perhitungan akan bernilai pada setiap factor yang mempengaruhi dalam setiap keputusan dari data yang akan diproses.(Afrianty \& Umbara, 2016)

Proses seleksi peneriman calon karyawan juga dilakukan melalui perhitungan metode MFEP melaui nilai bobot (Maharani \& Nata, 2020).

Dalam perhitungan dengan menggunakan metode MFEP dilakukan melalui 4 langkah, yaitu :

1. Mencari dan menentukan kriteria yang dibutuhkan

2. Pemberian bobot yaitu, pembobotan kepada faktor yang digunakan dengan total pembobotan adalah dengan nilai 1 (satu), proses ini sangat penting. Perhitungan pembobotan dapat dilakukan dengan menggunakan rumus :

$W F 1+W F 2+W F 3=1$

$W F=$ weight factor 
3.Evaluasi factor weight, proses ini melakukan perhitungan perkalian nilai bobot dengan nilai alternatif, dengan menggunakan rumus:

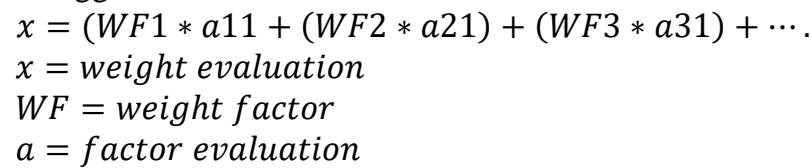

4.Menghitung weight evaluation, adalah proses perhitungan nilai evaluasi factor weight sebelumnya dan membagi dengan banyaknya data, perhitungan ini menggunakan rumus:

$$
\begin{aligned}
& X=x 1+x 2+x 3+\cdots .) / n \ldots . . . \\
& X=\text { total evaluation } \\
& x=\text { weight evaluation } \\
& n=\text { jumlah weight evaluation }
\end{aligned}
$$

Dalam penelitian ini menggunakan teknik penelitian kuantitatif dengan tipe deskriptif yang dilakukan dengan menentukan aspek Pendidikan, aspek Target, aspek Sikap, setelah aspek tersebut ditentukan, maka metode ini akan mencari gap antara profile dengan keadaan data dari pelamar, dengan metode ini ditentukan presentasi kedua unsur aspek dan ditotal, kemudian dilakukan proses perangkingan yang akan menentukan alternative yang optimal, yaitu karyawan yang layak untuk dipertimbangkan.Tahap berikutnya perbandingan dilakukan antara kemampuan individu dengan kualifikasi yang telah ditetapkan khususnya pada metode profile matching sehingga didapatkan gap dimana semakin kecil nilai yang didapatkan maka bobot nilai semakin besar. Core Factor dan secondary factor menjadi perhitungan berikutnya dengan memberikan besaran prosentase untuk kedua faktor tersebut. Dalam penelitian ini Core factor diberikan sebanyak 60\% dan $40 \%$ untuk secondary factor. Pemberian rangking adalah proses perhitungan hasil akhir untuk menentukan karyawan yang akan diterima diperusahaan. Dengan memberikan prosestasi untuk faktor pendidikan $=0,2$, faktor target $=0,5$, faktor sikap $=0,3$

\section{HASIL DAN PEMBAHASAN}

Langkah awal adalah penentuan kritera dan pembobotan yang diinginkan dari calon karyawan. Berikut kriteria yang ditampilkan pada table 1.

Sumber: Hasil penelitan

Tabel 1.Atribut Kriteria

\begin{tabular}{cl}
\hline Aspek & Kriteria \\
\hline A1 & Nama sekolah (CF) \\
A2 & Jurusan sesuai (CF) \\
A3 & Nilai IPK memenuhi (CF) \\
A4 & Tahun kelulusan \\
A5 & Workshop/kursus relevan \\
A6 & Pengalaman kerja dibidang yang sesuai (CF) \\
A7 & Proyek yg pernah ditangani (CF) \\
A8 & Kesesuaian gaji \\
A9 & Domisili \\
A10 & Jujur (CF) \\
A11 & Bertanggungjawab (CF) \\
A12 & Disiplin (CF) \\
A13 & Kerjasama \\
A14 & Komunikatif (SF) \\
A15 & Percaya Diri \\
\hline
\end{tabular}




\section{Computer Science (CO-SCIENCE)}

Volume 1 No. 2 Juli 2021 | E-ISSN: 2774-9711

Aspek pendidikan dikelompokan dalam aspek A1 untuk kriteria nama sekolah, berkaitan dengan alumni lulusan sekolah mana, A2 untuk jurusan harus sesuai dengan bidang pekerjaan yang ditawarkan. A3 untuk standar minimal nilai indeks pretasi komulatif (IPK) yang harus dipenuhi oleh calon karyawan, A4 merupakan ketrampilan tambahan yang pernah didapat melalui kegiatan workshop atau kursus yang relevan dengan bidang studi.

Aspek target merupakan penilaian dengan prosentase yang lebih besar dari kedua aspek lainnya . Hal ini dapat digunakan oleh perusahaan untuk menentukan posisi yang pas secara kompetensi. Melalui pengalaman kerja pada bidang yang sesuai (A6), pernah menangani proyek dalam bidang pekerjaan tersebut(A7), Kesesuaian gaji menjadi bagain penting dalam aspek ini, karena perusahaan akan menyesuaikan dengan anggaran yang ada (A8), jarak tempuh dalam perjalanan dari rumah menuju tempat kerja menjadi penilaian penting sebagai bentuk efisiensi waktu, (A9).

Aspek sikap, melalui pengujian yang berkaitan dengan personality calon karyawan seperti kejujuran (A10), seberapa besar rasa tanggungjawab terhadap perkerjaan (A11), Disiplin dalam kehadiran (A12), Kerjasama dalam satu tim (A13), dapat membangun komunikasi yang baik dengan rekan sekerja maupun atasa(A14), memiliki rasa percaya diri untuk dapat menyelesaikan suatu pekerjaan (A15).

Ada beberapa kriteria yang dijadikan sebagai penilaian penting dalam setiap aspek yang biasa disebut dengan core factor (CF), dimana core factor menjadi penilaian utama yang memiliki prioritas selebihnya kriteria tersebut disebut secondary factor .

Tabel2. Penilaian Profil dan Nilai Standar

\begin{tabular}{|c|c|c|c|c|c|c|c|c|c|c|c|c|c|c|c|}
\hline \multirow[b]{2}{*}{ Nama } & \multicolumn{5}{|c|}{ Aspek Pendidikan } & \multicolumn{4}{|c|}{ Aspek Target } & \multicolumn{6}{|c|}{ Aspek Sikap } \\
\hline & $\begin{array}{c}\text { A } \\
1 \\
\end{array}$ & $\begin{array}{c}\text { A } \\
2 \\
\end{array}$ & $\begin{array}{c}\text { A } \\
3 \\
\end{array}$ & $\begin{array}{l}\text { A } \\
4 \\
\end{array}$ & $\begin{array}{l}\text { A } \\
5 \\
\end{array}$ & $\begin{array}{c}\text { A } \\
6 \\
\end{array}$ & $\begin{array}{c}\text { A } \\
7 \\
\end{array}$ & $\begin{array}{l}\text { A } \\
8 \\
\end{array}$ & $\begin{array}{c}\text { A } \\
9 \\
\end{array}$ & A10 & A11 & A12 & A13 & A14 & A15 \\
\hline $\mathrm{C} 1$ & 4 & 4 & 5 & 5 & 4 & 5 & 5 & 4 & 4 & 4 & 4 & 4 & 5 & 5 & 4 \\
\hline $\mathrm{C} 2$ & 4 & 5 & 5 & 5 & 4 & 4 & 4 & 5 & 4 & 4 & 4 & 4 & 5 & 5 & 5 \\
\hline $\mathrm{C} 3$ & 4 & 5 & 5 & 5 & 5 & 5 & 5 & 5 & 3 & 4 & 4 & 5 & 5 & 5 & 5 \\
\hline $\mathrm{C} 4$ & 4 & 5 & 5 & 5 & 4 & 5 & 5 & 5 & 5 & 5 & 5 & 5 & 5 & 5 & 5 \\
\hline C5 & 4 & 4 & 5 & 5 & 4 & 4 & 4 & 5 & 3 & 5 & 5 & 5 & 5 & 5 & 5 \\
\hline C6 & 4 & 4 & 5 & 5 & 4 & 4 & 5 & 5 & 3 & 5 & 5 & 5 & 5 & 5 & 5 \\
\hline C7 & 4 & 4 & 5 & 5 & 4 & 4 & 4 & 5 & 5 & 5 & 5 & 5 & 5 & 5 & 5 \\
\hline C8 & 4 & 5 & 5 & 5 & 4 & 4 & 4 & 5 & 5 & 5 & 5 & 5 & 5 & 5 & 5 \\
\hline C9 & 4 & 4 & 5 & 5 & 4 & 5 & 5 & 5 & 5 & 5 & 5 & 5 & 5 & 5 & 5 \\
\hline $\mathrm{C} 10$ & 4 & 4 & 5 & 5 & 4 & 4 & 4 & 5 & 3 & 5 & 5 & 5 & 5 & 5 & 5 \\
\hline $\begin{array}{l}\text { Nilai } \\
\text { standar }\end{array}$ & 4 & 5 & 4 & 3 & 3 & 4 & 4 & 3 & 3 & 4 & 4 & 4 & 4 & 4 & 3 \\
\hline
\end{tabular}

Sumber: Hasil penelitian

Tabel 3 Perhitungan Gap Pendidikan dan Target

\begin{tabular}{|c|c|c|c|c|c|c|c|c|c|c|c|c|c|c|c|c|}
\hline \multirow[b]{2}{*}{ Nama } & \multicolumn{6}{|c|}{ aspek pendidikan } & \multicolumn{5}{|c|}{ aspek target } & \multicolumn{5}{|c|}{ aspek sikap } \\
\hline & $\begin{array}{c}\text { A } \\
1\end{array}$ & $\begin{array}{c}\mathrm{A} \\
2\end{array}$ & A & & & $\begin{array}{c}\text { A } \\
5\end{array}$ & $\begin{array}{l}\text { A } \\
6\end{array}$ & $\begin{array}{l}\text { A } \\
7\end{array}$ & $\begin{array}{l}\text { A } \\
8\end{array}$ & $\begin{array}{l}\text { A } \\
9\end{array}$ & A10 & A11 & A12 & A13 & A14 & A15 \\
\hline $\mathrm{C} 1$ & 0 & -1 & 1 & 2 & & 1 & 1 & 1 & 1 & 1 & 0 & 0 & 0 & 1 & 1 & 1 \\
\hline $\mathrm{C} 2$ & 0 & 0 & 1 & 2 & & 1 & 0 & 0 & 5 & 1 & 0 & 0 & 0 & 1 & 1 & 2 \\
\hline $\mathrm{C} 3$ & 0 & 0 & 1 & 2 & 2 & 2 & 1 & 1 & 4 & 0 & 0 & 0 & 1 & 1 & 1 & 2 \\
\hline $\mathrm{C} 4$ & 0 & 0 & 1 & 2 & & 1 & 1 & 1 & 0 & 2 & 1 & 1 & 1 & 1 & 1 & 2 \\
\hline $\mathrm{C} 5$ & 0 & -1 & 1 & 2 & & 1 & 0 & 0 & 1 & 0 & 1 & 1 & 1 & 1 & 1 & 2 \\
\hline C6 & 0 & -1 & 1 & 2 & & 1 & 0 & 1 & 5 & 0 & 1 & 1 & 1 & 1 & 1 & 2 \\
\hline C7 & 0 & -1 & 1 & 2 & & 1 & 0 & 0 & 4 & 2 & 1 & 1 & 1 & 1 & 1 & 2 \\
\hline C8 & 0 & 0 & 1 & 2 & & 1 & 0 & 0 & 0 & 2 & 1 & 1 & 1 & 1 & 1 & 2 \\
\hline C9 & 0 & -1 & 1 & 2 & & 1 & 1 & 1 & 1 & 2 & 1 & 1 & 1 & 1 & 1 & 2 \\
\hline $\mathrm{C} 10$ & 0 & -1 & 1 & 2 & & 1 & 0 & 0 & 5 & 0 & 1 & 1 & 1 & 1 & 1 & 2 \\
\hline
\end{tabular}

Sumber: Hasil penelitian

Nilai profil dari kriteria akan dikurangi dengan nilai standar dimana menghasilkan pemetaan gap yang digunakan untuk Perhitungan pembobotan.Pada metode MFEP diberikan penilaian untuk faktor pendidikan sebesar 0,2 , target= 0,5 dan sikap $=0,3$ 
Computer Science (CO-SCIENCE)

Volume 1 No. 2 Juli 2021 |E-ISSN: 2774-9711

Tabel 4 Penilaian Faktor Kriteria dan Bobot pada Metode MFEP

\begin{tabular}{ccccc}
\hline Faktor nilai & Pendidikan & Targaet & Sikap & $\begin{array}{l}\text { Jumlah } \\
\text { Bobot }\end{array}$ \\
\hline Nilai Bobot & 0.2 & 0.5 & 0.3 & 1 \\
C1 & 4.30 & 4.50 & 4.75 & \\
C2 & 4.50 & 3.88 & 4.58 & \\
C3 & 4.30 & 3.88 & 4.50 & \\
C4 & 4.50 & 4.38 & 4.33 & \\
C5 & 4.30 & 4.88 & 4.33 & \\
C6 & 4.30 & 3.88 & 4.33 & \\
C7 & 4.30 & 3.75 & 4.33 & \\
C8 & 4.50 & 4.63 & 4.33 & \\
C9 & 4.30 & 4.25 & 4.33 & \\
C10 & 4.30 & 4.00 & 4.33 & \\
\hline
\end{tabular}

Sumber : Hasil penelitian

Nilai bobot memberikan perbedaan tingkat selisih kompetensi level dengan nilai tertinggi adalah 0.5 yang diberikan untuk bobot target dan terendah adalah 0.2 untuk bobot pendidikan. Penilaian bobot ini akan digunakan sebagai acuan untuk mendapatkan nilai pembobotan.

Tabel 5.Hasil Pembobotan Pendidikan dan Target dengan Metode Profile Matching

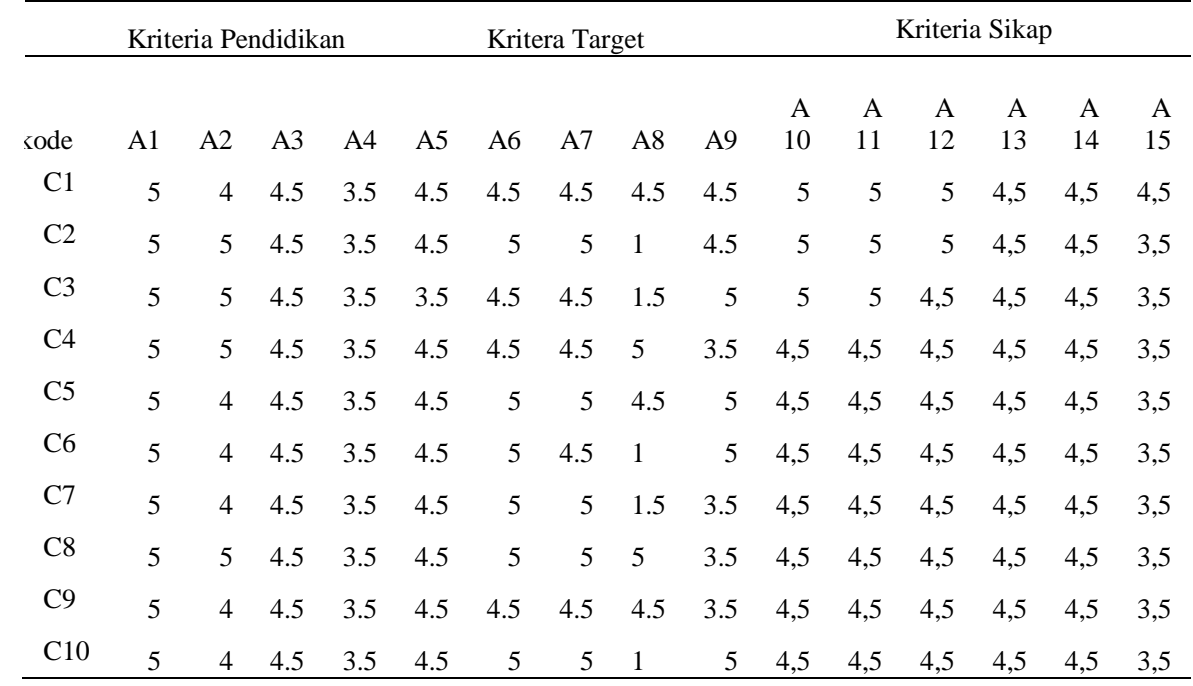

Sumber: Hasil penelitian

Untuk memberikan alternatif perhitungan dengan metode lain yang lebih sederhana tapi tidak mengurangi esensi pokok dari tujuan seleksi pencarian calon karyawan sebagai altenatif yang dimiliki maka digunakan metode multi factor evaluation process (MFEP). Langkah-langkah dalam perhitungan metode ini, yaitu:

1. Penetuan kriteria terdiri dari kriteria pendidikan, target dan sikap. Masing - masing memiliki nilai bobot untuk kriteria pendidikan 0,2 , kriteria target 0,5 dan kriteria sikap memiliki nilai bobot 0,3 .

Tabel 6. Penetuan Faktor Kriteria dan Nilai Bobot dengan Metode MFEP

$$
\text { Faktor Pendidikan Target Sikap } \begin{aligned}
& \text { Jumlah } \\
& \text { Bobot }
\end{aligned}
$$


Computer Science (CO-SCIENCE)

Volume 1 No. 2 Juli 2021 |E-ISSN: 2774-9711

\begin{tabular}{ccccc}
\hline $\begin{array}{c}\text { Nilai } \\
\text { Bobot }\end{array}$ & 0,2 & 0,5 & 0,3 & 1 \\
C1 & 4,5 & 4,5 & 4,80 & \\
C2 & 4,5 & 4,1 & 4,67 & \\
C3 & 4,3 & 4,0 & 4,45 & \\
C4 & 4,3 & 4,4 & 4,37 & \\
C5 & 4,3 & 4,90 & 4,37 & \\
C6 & 4,3 & 4,05 & 4,37 & \\
C7 & 4,5 & 4,0 & 4,37 & \\
C8 & 4,3 & 4,7 & 4,37 & \\
C9 & 4,3 & 4,3 & 4,37 & \\
C10 & 4,3 & 4,2 & 4,37 & \\
\hline
\end{tabular}

Sumber : Hasil penelitian

2. Menghitung pembobotan dengan metode MFEP, yang hasilnya dapat dilihat pada tabel 7 .

Tabel 7. Hasil Pembototan dengan Metode MFEP

Sumber: Hasil penelitian

\begin{tabular}{lccc}
\hline Nama & Pendidikan & Target & Sikap \\
\hline C1 & 0,90 & 2,25 & 1,44 \\
C2 & 0,90 & 2,05 & 1,40 \\
C3 & 0,86 & 2,00 & 1,34 \\
C4 & 0,86 & 2,20 & 1,31 \\
C5 & 0,86 & 2,45 & 1,31 \\
C6 & 0,86 & 2,03 & 1,31 \\
C7 & 0,90 & 2,00 & 1,31 \\
C8 & 0,86 & 2,35 & 1,31 \\
C9 & 0,86 & 2,15 & 1,31 \\
C10 & 0,86 & 2,10 & 1,31 \\
\hline
\end{tabular}

Hasil perhitungan pembototan digunakan untuk perhitungan nilai akhir. Evaluasi factor weight, proses ini melakukan perhitungan perkalian nilai bobot dengan nilai alternatif.

Tabel 8 Perangkingan dengan Metode Profile Matching

\begin{tabular}{clllcc}
\hline Nama & NP & NT & NS & Jumlah & Ranking \\
\hline C1 & 4.5 & 4.5 & 4.80 & 4.59 & 2 \\
C2 & 4.5 & 4.1 & 4.67 & 4.35 & 6 \\
C3 & 4.3 & 4.0 & 4.45 & 4.2 & 11 \\
C4 & 4.3 & 4.4 & 4.37 & 4.37 & 5 \\
C5 & 4.3 & 4.90 & 4.37 & 4.62 & 1 \\
C6 & 4.3 & 4.05 & 4.37 & 4.2 & 10 \\
C7 & 4.5 & 4.0 & 4.37 & 4.21 & 9 \\
C8 & 4.3 & 4.7 & 4.37 & 4.52 & 3 \\
C9 & 4.3 & 4.3 & 4.37 & 4.32 & 7 \\
C10 & 4.3 & 4.2 & 4.37 & 4.27 & 8 \\
\hline
\end{tabular}

Sumber: Hasil penelitian

Akumulasi penjumalahan core factor dan secondary factor pada nilai pendidikan (NP), nilai target (NT) dan nilai sikap (NS) memberikan informasi peringkat dari calon atau kandidat karyawan yang akan dipertimbangkan untuk diterima.

Tabel 9 Hasil Perhitungan Perankingan dengan Metode MPEF

\begin{tabular}{clc}
\hline Nama & Jumlah & Rangking \\
\hline C1 & 0.504 & 2 \\
C2 & 0.468 & 6 \\
C3 & 0.461 & 8 \\
C4 & 0.488 & 4 \\
C5 & 0.511 & 1 \\
C6 & 0.455 & 9 \\
\hline
\end{tabular}

http://jurnal.bsi.ac.id/index.php/co-science 


\begin{tabular}{ccc}
\hline $\mathrm{C} 7$ & 0.448 & 10 \\
$\mathrm{C} 8$ & 0.501 & 3 \\
$\mathrm{C} 9$ & 0.476 & 5 \\
$\mathrm{C} 10$ & 0.462 & 7 \\
\hline
\end{tabular}

Sumber: Hasil penelitian

Hasil perhitungan jumlah rata-rata pembobotan yang dibagi dengan faktor nilai pendidikan, nilai target dan nilai sikap memberikan informasi peringkat dari calon karyawan yang dapat dipertimbangkan untuk dapat diterima.

\section{KESIMPULAN}

Metode profile matching dan multi factor evaluation process (MFEP) sangat membantu dalam mempertimbangkan pengambilan keputusan untuk memilih kandidat yang ada sesuai dengan kebutuhan sehingga bagian sumber daya manusia (SDM) akan lebih objektif dalam menentukan calon karyawan dan dapat menghemat waktu.Pada penelitian ini kandidat dengan hasil tertinggi melaui metode profile matching dengan nilai 4,62 sedangkan metode MFEP dengan nilai 0,511 yang mana urutan tertinggi mengacu pada kandidat yang sama. Alangkah baiknya disarankan dapat dikembangkan dengan pembuatan aplikasi yang sedang trend saat ini.

\section{REFERENSI}

Afrianty, I., \& Umbara, R. (2016). Sistem Pendukung Keputusan (SPK) Menentukan Kelayakan Calon Penerima Zakat Menerapkan Multi- Factor Evaluation Process (MFEP). Seminar Nasional Teknologi Informasi, Komunikasi Dan Industri (SNTIKI) 8, November, 87-94. http://ejournal.uinsuska.ac.id/index.php/SNTIKI/article/view/2813

Britta, M. (2021). 5 Kendala Rekrutmen Karyawan Sering dialami dan Cara Mengatasinya (Issue April). https://sampingan.co.id/post/kendala-rekrutmen-dan-cara-mengatasi

Faizal, E. (2017). Implementasi Metode Profile matching untuk Penentuan Penerimaan Usulan Penelitian Internal Dosen STMIK El Rahma Implementasi Metode Profile matching untuk Penentuan Penerimaan Usulan Penelitian Internal Dosen STMIK El Rahma. Implementasi Metode Profile Matching Untuk Penentuan Penerimaan Usulan Penelitian Internal Dosen STMIK El Rahma, 6(January 2014), 60-65.

Frieyadie, F. (2016). Penggunaan Metode Profile Matching Untuk Sistem Penunjang Keputusan Kenaikan Jabatan Pada Instansi Pemerintah. Paradigma - Jurnal Komputer Dan Informatika, 18(2), 75-80. http://ejournal.bsi.ac.id/ejurnal/index.php/paradigma/article/view/1228

Ikhlas, M. (2019). Penerapan Metode Mfep (Multifactor Evaluation Process) Dalam Pengambilan Keputusan Pemilihan Bibit Kelapa Sawit Terbaik. Jurnal Sains Dan Teknologi: Jurnal Keilmuan Dan Aplikasi Teknologi Industri, 19(1), 16. https://doi.org/10.36275/stsp.v19i1.128

Maharani, D., \& Nata, A. (2020). PERBANDINGAN METODE MFEP DAN MAUT DALAM SELEKSI CALON PESERTA OLIMPIADE SAINS NASIONAL ( OSN ) Sistem Informasi, STMIK Royal Kisaran PENDAHULUAN OSN ( Olimpiade Sains Nasional ) merupakan kegiatan perlombaan dibidang sains dan ilmu pengetahuan yang diran. JURTEKSI (Jurnal Teknologi Dan Sistem Informasi), VI(3), 247. https://jurnal.stmikroyal.ac.id/index.php/jurteksi/article/view/793/414

Nashrullah, M. I., Abdillah, G., \& Renaldi, F. (2016). SISTEM PENDUKUNG KEPUTUSAN UNTUK REKOMENDASI PROMOSI JABATAN MENGGUNAKAN METODE PROFILE MATCHING DAN ELECTRE Muhammad. Prosiding SNST Ke-7, Pros. SNST ke-7, 196-201.

Putra, J. L., Raharjo, M., Sandi, T. A. A., Ridwan, R., \& Prasetyo, R. (2019). Implementasi Algoritma Apriori Terhadap Data Penjualan Pada Perusahaan Retail. Jurnal Pilar Nusa Mandiri, 15(1), 85-90. https://doi.org/10.33480/pilar.v15i1.113

Ramadhan, M. H., \& Yusfrizal. (2019). ANALISIS DAN PENERAPAN METODE MULTIFACTOR EVALUATION PROCESS (MFEP) DALAM MENENTUKAN BIBIT TANAMAN BUNCIS YANG LAYAK UNTUK DIBUDIDAYAKAN. Jurnal Sistem Informasi Kaputama (JSIK), 3(1), 18-26.

Sutinah, E. (2017). Sistem Pendukung Keputusan Menggunakan Metode Profile Matching dalam Pemilihan Salesman Terbaik. Informatics for Educators and Professionals, 2(1), 234409.

Syahrizal, M., \& Maulidza, D. (2018). Sistem Pendukung Keputusan Pemilihan Televisi Bekas Terbaik Dengan Menggunakan Metode Multi Factor Evaluation Process (MFEP). Jurikom, 5(4), 382-389.

Turaina, R. (2017). Spk Dalam Pemilihan Siswa Kelas Unggul Menggunakan Metode Mfep Di Smp N 2 Solok. Edik Informatika, 3(2), 125-135. https://doi.org/10.22202/ei.2017.v3i2.1662 